\title{
Atom Probe Field Ion Microscopy of \\ Type 308 CRE Stainless Steel Welds
}

\author{
S. S. Babu†, S. A. David, J. M. Vitek and M. K. Miller \\ Metals and Ceramic Division, Oak Ridge National Laboratory, Oak Ridge, TN 37831. \\ †Assignment to Oak Ridge National Laboratory from The Pennsylvania State University, PA 16802. \\ Introduction
}

Addition of controlled residual elements (CRE) such as $0.007 \mathrm{wt} \%$ boron to a commercial type 308 stainless steel welds improved the creep rupture properties [1-3]. In these welds, during high temperature service, $\mathrm{M}_{23} \mathrm{C}_{6}$ carbides form along austenite-ferrite interface and ferrite transforms to Sigma phase. It is speculated that $\mathrm{M}_{23} \mathrm{C}_{6}$ carbideaustenite interface may be strengthened by segregation of boron to the interface. According to this speculation, the boron should be associated with the regions of $\mathrm{M}_{23} \mathrm{C}_{6}$ carbide precipitation, i.e.; near the original ferrite-austenite interface boundaries. However, to date there is no proof for such preferential segregation of boron to the interphase interface. Hence, boron distribution and microstructure development in a boron containing type 308 stainless steel welds were studied.

\section{Procedure}

Autogeneous gas tungsten arc welds were made on stainless steel plates of following composition $\mathrm{Fe}-0.055 \mathrm{C}-20 \mathrm{Cr}-9.9 \mathrm{Ni}-0.013 \mathrm{~N}-0.006 \mathrm{~B}$ (wt.\%). After welding, the weld metal zone was carefully removed. The weld metal specimens were then subjected to either of the following two thermal aging treatments; (1) $100 \mathrm{~h}$ at $923 \mathrm{~K}$, and (2) $1000 \mathrm{~h}$ at $923 \mathrm{~K}$. The samples in as-welded condition and aged conditions were examined in a Philips-CM12 transmission electron microscope. To enable quantitative measurement of boron redistribution, the atom probe field ion microscopy was used to study the distribution of boron.

Results and Discussion

In the as-welded condition, the boron-containing weld consists of both $\delta$-ferrite and austenite. After aging for $100 \mathrm{~h}$ at $923 \mathrm{~K}, \mathrm{M}_{23} \mathrm{C}_{6}$ carbides were observed along the

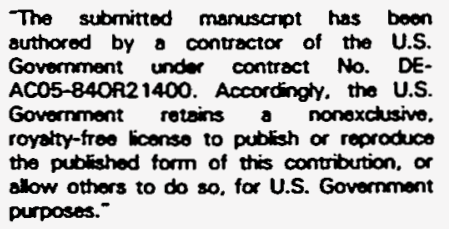




\section{DISCLAIMER}

Portions of this document may be illegible in electronic image products. Images are produced from the best available original document. 
ferrite-austenite interfaces. After aging for $1000 \mathrm{~h}$ at $923 \mathrm{~K}$, most of the ferrite had transformed to Sigma phase. This microstructural evolution is similar to that observed in commercial SS308 stainless steel [1-3].

The atom probe field ion microscopic analysis showed the segregation of boron and carbon to the austenite-ferrite interface, in the as-welded state. The boron concentration at the interface was found to be $\sim 2$ at. $\%$ and that of carbon was $\sim 6$ at.\%. The segregation of boron to the ferrite-austenite interfaces may influence the precipitation reactions during high temperature aging. It is known that boron segregates preferentially to the austeniteaustenite grain boundary in austenitic stainless steels [4]. However, the boron segregation to an austenite-ferrite interface is now revealed for the first time by this result. As boron is a boundary strengthener, its segregation may lead to improved creep rupture properties. The carbon enrichment at the ferrite-austenite interfaces aids in the formation of $\mathrm{M}_{23} \mathrm{C}_{6}$ carbides during high temperature aging.

The equilibrium solidification and partitioning in boron containing weld were simulated using ThermoCalc ${ }^{\mathrm{TM}}$ software [5]. The calculations showed that the solubility of boron in ferrite and austenite is small. According to equilibrium thermodynamics, the liquid becomes enriched in boron, as the solidification proceeds. The calculated ratio of carbon to boron concentration at the interface is $\sim 3.9$. The ratio of carbon to boron concentrations observed in the atom probe integrated composition profile analysis is $\sim 3.5$. Hence, the ThermoCalc ${ }^{\mathrm{TM}}$ calculations support the experimental results.

\section{Conclusions}

The microstructural evolution of boron containing stainless steel 308 weld, during high temperature aging, was found to be similar to that of commercial SS308 welds. Atom probe analysis clearly established that boron and carbon segregate to the ferrite-austenite interface. Thermodynamic calculations suggest that the segregation phenomenon is due to the preferential partitioning of boron and carbon to the liquid during solidification. Further work is necessary to study the redistribution of boron in various stages of high temperature aging. 
This research was sponsored by the Division of Materials Science, U. S. Department of Energy, under contract DE-AC05-84OR21400 with Martin Marietta Energy Systems, Inc.

References

1. R. T. King, J. O. Steigler and G. M. Goodwin, Welding Journal, 53, 1974, 307s 313s.

2. N. C. Binkley, R. G. Berggren and G.M. Goodwin, Welding Journal, 53, 1974, 91s 95s.

3. D. P. Edmonds, R. T. King and G. M. Goodwin, Report ORNL/TM-6177, January 1978.

4. L. Karlsson, H. Norden, and H. Odelius, Acta. Metall., 36, 1988, 1 - 12.

5. B. Sundman, B. Jansson, and J.-O. Andersson, Calphad, 9, 1985, 153-190.

\section{DISCLAIMER}

This report was prepared as an account of work sponsored by an agency of the United States Government. Neither the United States Government nor any agency thereof, nor any of their employees, makes any warranty, express or implied, or assumes any legal liability or responsibility for the accuracy, completeness, or usefulness of any information, apparatus, product, or process disclosed, or represents that its use would not infringe privately owned rights. Reference herein to any specific commercial product, process, or service by trade name, trademark, manufacturer, or otherwise does not necessarily constitute or imply its endorsement, recommendation, or favoring by the United States Government or any agency thereof. The views and opinions of authors expressed herein do not necessarily state or reflect those of the United States Government or any agency thereof. 